\title{
The Positive Mediating Impact of Teacher Helping Behaviour on HPWS and Teacher Performance in SHRM
}

\author{
Shareef Akanbi Ashade ${ }^{1}$, Mikail Ibrahim ${ }^{1}$, Harison Mohd Sidek ${ }^{1}$ \\ ${ }^{1}$ Faculty of Major Languages, University Science Islam Malaysia, Bandar Baru, Nilai 71800, Negeri Sembilan \\ Malaysia. \\ DOI: 10.29322/IJSRP.10.11.2020.p10774 \\ http://dx.doi.org/10.29322/IJSRP.10.11.2020.p10774
}

\begin{abstract}
Incorporating the strategic human resource management research with teaching staff views of their performance. In this study, it proposed that the human resource management practices of a high-performance work system enhance teacher performance in the school context. However, the integration of Helping Behaviour as a mediator between HPWS and Teacher performance encourage teachers to engage in cooperative behaviors among their colleagues and the students who are essential in achieving its superior performance. The results based on the data from six education district in Lagos State Nigeria. The 322 teachers significantly embraced the proposed theoretical framework and enliven the effect of a teacher helping behavior on high-performance work system and teacher performance adopting Structural Equation Modelling (SEM) analysis. Results of the analysis revealed that collective teacher Helping Behaviour moderated the link between HPWS and Teacher Performance indirectly. Consequently, HPWS directly influenced the teacher performance.
\end{abstract}

Index Terms- Helping Behaviour, High-Performance Work System (HPWS), SHRM, Teacher Performance

\section{INTRODUCTION}

$\mathrm{T}$ he continuous expeditious change that rocks the Economic environment globally is characterized to reshape customers, investors' demands, and high increasing product-market competitions. However, in order to compete successfully in this environment, organizations need continuous improvement of their performance by reducing costs, innovating products and improving quality of their products. Meanwhile, human resources are considered to be one of the most valuable resources of today's establishment. The way of managing employee is becoming more significant because many other sources of competitive success are less potent to meet up the market challenges. Therefore new mechanism should be developed as a tool for human resource management and strategy.

This paper examines the relationship that might exist between high-performance work system (HPWS) of strategic Human Resource practice and teacher effectiveness. Researchers of strategic human resource management (SHRM) has found a positive relationship between high-performance work systems (HPWS) and employee performance (Boxall \& Macky, 2016; Combs, Liu, Hall, \& Ketchen, 2006). However, the introduction of a teacher helping behavior paradigm in the education ministry might facilitate inner drive of the individual that enhance quality performance.

The researcher contest that helping behavior is one of the important missing factors within the school system among the teaching staff and likewise the policy makers within the ministry. The amalgamation of HR systems and employee helping behavior could offer a more coherent understanding of how helping can be exploited in various circumstances. Strategic HR researchers such as Collins \& Smith (2006) proclaim that through appropriate HR systems, organizations can influence employees' behaviors and build social capital as a potential source of competitive. Based on this discussion, the researcher proposed the hypothesized model and hypothesis for this study as shown in Figure 1. 


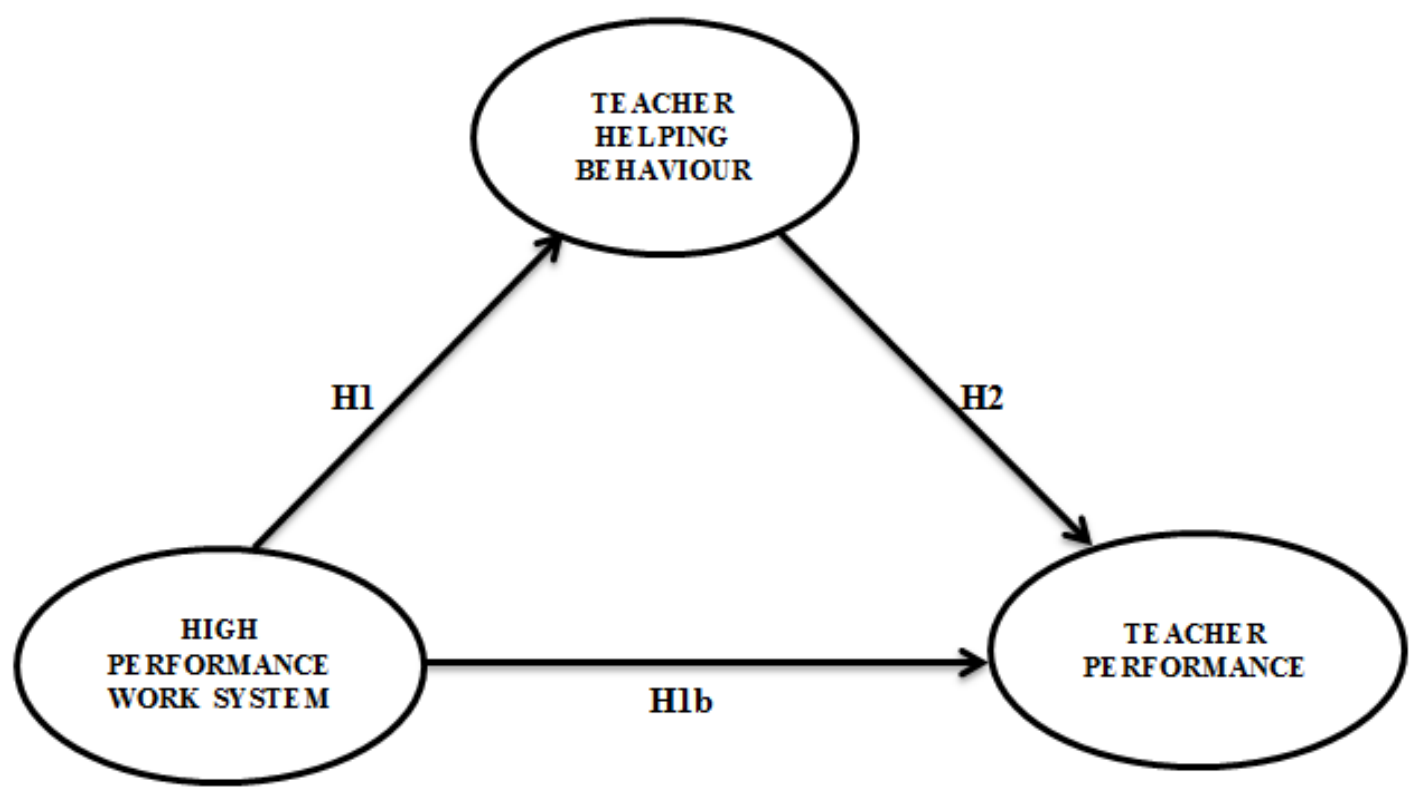

Figure 1: Hypothesised Model of the Study.

\section{High-PERFORMANCE WORK SYSTEM (HPWS)}

Early before now, organizations are facing increased competitive challenges due to globalization, rapid technological advancement, greater innovation, demands for higher quality product and customer service, the risks and rewards of managing a diverse workforce. To meet up with these challenges and sustain a competitive advantage; organizations must combine human resource (HR) practices into an overall High-Performance Work Systems (HPWS) that enhances employee involvement and performance. According to Datta, Guthrie \& Wright (2005), organizations that use HPWSs or systems of HR practices designed to enhance staff competencies, motivation, and performance associated with lower employee turnover, higher labor productivity, and improved overall organization performance.

Also, it has been introduced into literature as a bundle of HR practices which are being used in different combinations according to culture, climate and business strategies of the organization. HR practices shape the employee's behavior and attitude toward the organization strategies and goals (Guzzo \& Noonan, 1994). These practices are known by various names according to their use and circumstances like (a) Highperformance Management (b) high involvement management(c) high commitment management (Hegan, 2006). The revolution in workplace gives more popularity of HPWS, reflecting the increasing number of the organization taking proactive steps to apply some form of HPWS (Nadler, 1992) and it also develops a psychological link between employees and employer by creating trust in each other (Arthur, 1994; Pfeffer, 1996).

HPWS is a combination of HR practices such as skill training, compensation policy, and workforce participation that complement organizational work structures and processes. It also maximizes responsibility, compliance, and adaptability of employees (Bohlander \& Snell, 2010). HPWSs focus on systemization of the interrelated parts of an organization that complements one another to accomplish the goals of the organization. So, the HPWS elements can have a direct influence on teacher performance. At the same time, the effect could be another way round through helping behavior as the mediator variables. The combination of these variables can also have a positive effect on teacher performance which will result to reshape school performance in general.

The investigation has shown that there is a relationship between HRM practices and organizational outcomes such as organizational performance, productivity, financial performance, innovation and employees' turnover (Huselid, 1995). It was noted that larger organizations are more likely to engage in best practice selection, due to the associated costs of selection as a best practice, often meaning that the smaller organization is unable to meet the required costs of meeting the best practice selection requirements (Johnson, 2000). It is interesting to note, however, that even though there are significant costs associated with recruiting and selecting the most appropriate employee for the job, long-term, costs that could be saved due to making optimal appointments that are important, and could thus outweigh any initial costs associated with finding an appropriate employee.

Besides, the recruitment channels that are selected to locate the employee often have a significant bearing on his caliber and the organization. Decisions must be made as to whether an agency is used, or whether methods including newspaper advertisements, professional magazine advertising, internet recruitment, or headhunting locally, nationally or internationally are utilized for example. This decision will impact on the resulting appointment and therefore must carefully be considered to ensure the most appropriate appointees are selected.

Therefore, training should be packed in more comprehensive and goal-oriented manner that should be more than a reference to the specific operational task. The development of employees in multiple ways is a method for instilling commitment, 
as feedback of this undertaking can be felt through the employees improved performance. So, the enactment of effective training and development within an organization is highly essential for her goals to be realized (Enz \& Siguaw 2000).

\section{SHRM AND TEACHER PERFORMANCE}

Over the years, studies linked HRM practices and employee job performance, a larger number of researchers, was conducted on different parameters of the various countries (Munjuri, 2011; Boon, Den Hartog, Boselie, 2011; Karatepe, 2013, Sattar, Ahmad \& Hassan, 2015; Hassan, 2016). Most of their investigations showed a significant impact of SHRM practices on the performance of employees. Teacher performance is linked directly to School organizational performance. Therefore, successful school organizations consider the HRM practices as a crucial factor that directly affects the teachers' performance.

The practices of SHRM structure is a magnificent tool that can play a vital role in enhancing various HR practices. Inadequate staff recruitment, lack of training and weak compensation schemes for excellent job performance are determinants part of employees performance and their engagement at the workplace (Zheng and Lamond, 2010). On the other hand, Andrew and Sofian, (2012) cited that various SHRM practices such as freedom of performance, teamwork, engagement, and compensation also provide the placement of motivated and competent employees. Therefore, the intervention of SHRM are interrelated with the organizational development which largely contributes towards high levels of productivity and high-quality performance in organizations.

\section{TEACHER HELPING BEHAVIOUR}

The advancement intensity on the need for partnership, participation and the combination of joint-effort is highly critical in every organization for the effectiveness of interpersonal behaviors among employees (Griffin, Neal, \& Parker, 2007; Ilgen \& Pulakos, 1999). Moreover, likewise, the increasing globalization necessitates the sharing of information, products, and services, across cultures. Such sharing mostly builds upon employees' cooperation and their wiliness to help each other propelling the organization attains the set targets. Hence, helping behavior is an inevitable entity that is strongly needed in organizational success. Helping behavior is among significant determinant success of the group and organizational performance (Podsakoff, Whiting, Podsakoff \& Blume, 2009; Podsakoff, MacKenzie, Paine, \& Bachrach, 2000).

Moreover, has become more important in light of movement toward greater employee involvement, while Boxall \& Macky (2009) observe it as interactive work structures and human resource flexibility within organizations. However, the helping behavior involves actions by which individuals positively affect others. Inaddition, Becker \& Huselid (2011), have suggested a need to understand better HR systems' influence on employees and relationships formed among them and also argued that HR systems may affect employees' climate perception by symbolically signaling and directly communicating key organizational norms and values. Aside from that, the crucial aspect of HR systems most directly upon employees in a collective manner, since their responsibility is to manage the potential resources of the organization.

Also, empirical evidence also shows that employees are inclined to engage in extra-role, contextual performance if they perceive a high level of support from the organization (Rhoades \& Eisenberger, 2002). For example, Piercy, Cravens, Lane, and Vorhies (2006) showed that salespersons' perceptions of the organization's concern for them could predict their performance. Extending Piercy et al. from the individual level of analysis to the unit level of analysis, then it can be proclaimed that once a shared perception about the unit's concern for employees is formed at the unit level, then a shared reciprocal obligation will emerge at the unit level. Which will induce not only in-role collective service performance but also collective employee behaviors to contribute above the call of duty and engage in helping behavior toward coworkers.

Summarily, it has argued that the HR practices of an HPWS can facilitate dual climates of concern for customers and at the same time concern for employees, which in turn may encourage employees to engage in service performance and helping behavior that is essential for achieving superior teacher performance. The hypothesized model is rooted from the insight that HPWS and teacher performance could be influenced indirectly through helping behavior. Therefore, the researcher proposed the following hypothesis:

Proposed Hypothesis

H1: HPWS would be significantly related to teacher helping behavior.

H1b: HPWS would be significantly related to teacher helping behavior.

H2: Teacher helping behavior would be substantially related to teacher performance.

\section{RESEARCH METHODOLOGY}

This study is a quantitative survey using a questionnaire to get the opinion of government secondary schools teachers in Lagos State. Also, it can reach a significant number of people in a relatively quick amount of time and with minimal expenditure. The purpose of the survey was to provide adequate information on the perceptions of the teachers in Lagos State public schools regarding the role of how teacher helping behavior as a mediator variable can promote their job performance and HPWS respectively.

\section{DATA ANALYSIS PROCEDURES}

The researcher makes use of CFA to test whether each of the measurement items stipulated could load significantly onto the latent constructs they belong. Moreover, also to determine whether each construct was empirically distinct from the other. Also, James, Mulaik, \& Brett, (2006) suggested that Structural equation modeling was employed to provide a better balance of statistical power, that can simultaneously test both paths from an independent variable to a mediator. Moreover, likewise from the mediator to the dependent variable to examine the relationships proposed in the research model. 


\section{DEMOGRAPHIC DATA}

Data are collected directly from the teachers working in the government school Lagos state Nigeria. A total 410 respondents from the teacher were collected out of 600 questionnaires distributed among the six districts. However, 322 samples were fully answered of which 88 of respondents were rejected due to incomplete fill out of questionnaires. Finally, 322 samples are found suitable for analysis in this study.

Male respondents comprised of $25.5 \%$, which means 82 of the total respondents, and female employees contributed $74.5 \%$ that is 240 of the total respondents. The study revealed that Majority of the participants $(35.01 \%)$ had been employed for more than five years. $32.06 \%$ of employees had 6-10years of work experience while $11.05 \%$ had $11-15 \%$ years of work experience. $7.05 \%$ of respondents had their experience of work between 1620years. However, $4.0 \%$ have been employed between 21-25years while those with 26-30years of experience are $6.2 \%$. Additionally, $1.06 \%, .06 \%$, and $.09 \%$ have their work experience between 31 $35 y e a r s, 36-40 y e a r s$ and 41 years above respectively. Furthermore, Out of 322 respondents, 187 were B.Ed/HND graduates, 99 were Diploma/OND/NCE graduate while only 36 had M.ED. Unfortunately, none of the interviewees had Doctoral Degree. More so, out of the total sample surveyed, $69.03 \%$ of teachers were within 1-5years of training, $24.5 \%$ of respondents were within the age category of $6-10$ years; $3.1 \%$ were within the range of $11-15$ years; $1.9 \%$ and $1.2 \%$ were within the group of $16-20$ and 21 years and above respectively.

\section{RELIABILITY AND VALIDITY OF THE QUESTIONNAIRE}

The validity of the questionnaire was tested using Exploratory Factor Analysis (EFA). The results of EFA indicated that three underlying factors, namely, HPWS, a teacher helping behavior as well as teacher performance as predicted. 30 items consist the three factors. The inter-correlation among the items tested the starting of EFA as indicated by anti-image matrices showed that all the elements correlations between themselves more than .857.Additionally, The Kaiser-Meyer-Olkin measure of sampling adequacy was .930 , indicating the suitability of the data for EFA. Bartlett's Test of Sphericity was revealed to be statistically significant $(\mathrm{p}=.000)$, which indicates the satisfactory correlation between the items.
Meanwhile, the total variance of three factors explained $56.744 \%$ which showed that the items were able to measure HPWS which include (Staffing, Training, and Compensation), Teacher Helping Behaviour and teacher performance. The highest Eigenvalue was obtained by the first factor of 10.840 , while the other two factors showed the values of 1.7563 and 1.618, respectively. The majority of communaities estimates for each of the items were greater than .68 .

The rotated component matrix exhibited three solid components. The first element of HPWS was represented by the fourteen items indicating loadings ranging from .499 to 830 and explained $37.880 \%$ of the total variance. The second component of teacher behavior was represented by the four items showing loadings from .556 to .791 and explained $7.451 \%$ of the total variance. The last component of teacher performance was represented by the twelve items and demonstrated loadings ranging from .972 to .426 and explained $7.052 \%$ of the total variance.

\section{MeAsurement MODEL}

After the assessment of the EFA, a measurement model of each construct was examined by reviewing the estimated factor loadings for statistical significance and by examining the composite reliability and the variance extracted from that construct. However, each of the measurement items specified could load significantly onto the latent constructs with which they were associated and each construct which ranges from (.46 to .80) as shown in Figure 2.

The results of CFA indicated that the hypothesized threefactor model fit the data well $(\chi 2=59.855$, df $=32, \mathrm{p}=.002<$ $.005, \mathrm{RMSEA}=.055, \mathrm{GFI}=963, \mathrm{AGFI}=936, \mathrm{NFI}=.951, \mathrm{RFI}=$ $.931, \mathrm{CFI}=.976, \mathrm{TLI}=.966$ and $\mathrm{CFI}=.976)$ this findings indicate that the model possesses adequate discriminate validity. The results of the correlation matrix of the latent variables suggests a relatively high level of correlation coefficient between HPWS and Teacher Performance $(\mathrm{r}=.89)$.as well as the Teacher Helping Behaviour which indicator mediator between HPWS and Teacher Performance $(\mathrm{r}=.80)$ and $(\mathrm{r}=.80)$ respectively indicating that the relationship between each indicator variable and its respective latent variable was statistically significant $(\mathrm{p}<.01)$ suggesting that constructs used in this study were distinct. 


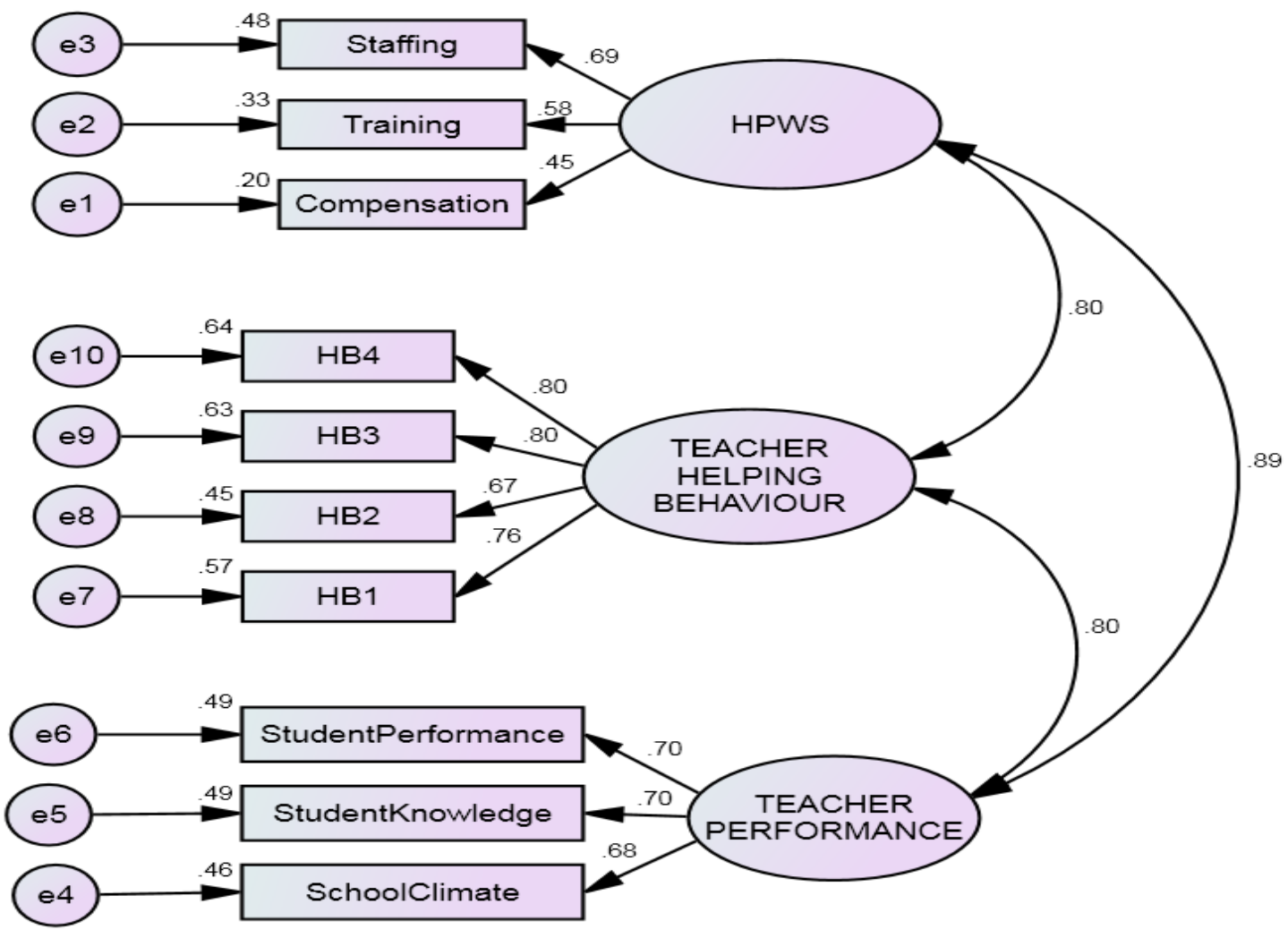

Figure 2: CFA Measurement Model of the Hypothesized Model

\section{Structural Equation Modelling (SEM)}

The employment of structural equation modeling provides a better balance of statistical power by simultaneously testing both paths from an independent variable to a mediator and from the mediator to the dependent variable (MacKinnon, Lockwood, Hoffman, West, \& Sheets 2002) to examine the relationships proposed in the research model. Therefore, the structural model was assessed by adding the predicted paths to the measurement model. A direct path from HPWS to teacher performance is indicating that part of the causal effect of HPWS on the teacher performance and a mediation effect of Teacher helping behavior through HPWS and teacher performance. The hypothesized research model in Figure 3 achieved an acceptable fit with this data $(\chi 2=59.855, \mathrm{df}=32, \mathrm{GFI}=.963, \mathrm{AGFI}=.936, \mathrm{NFI}=.951$, $\mathrm{RFI}=.931, \mathrm{IFI}=.976, \mathrm{TLI}=.966, \mathrm{CFI}=.976$ and $\mathrm{RMSEA}=$ $.052)$. 


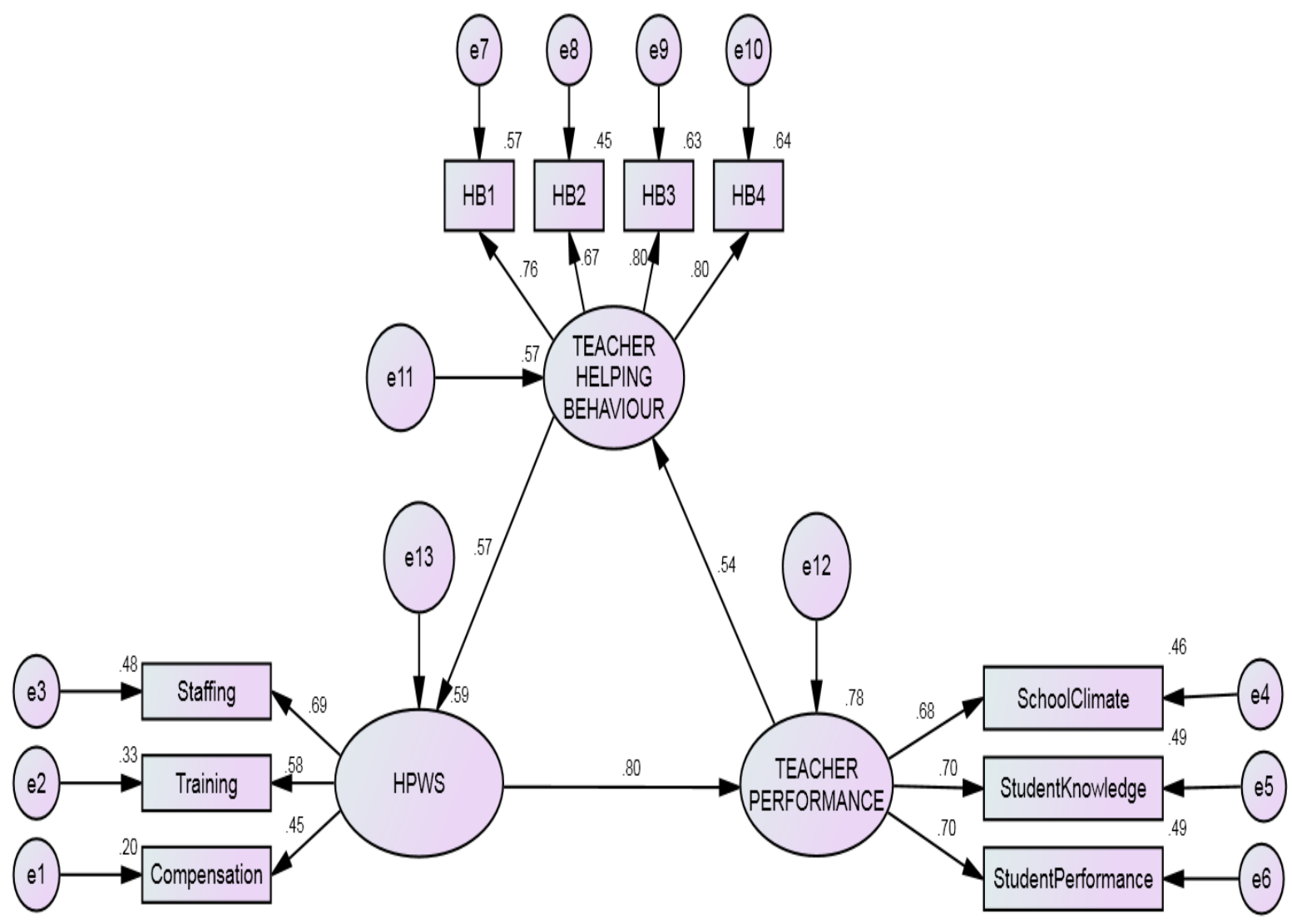

Figure 3: Path Model of the Hypothesized Model

In examining the structural parameter estimates, a strong positive relationship was found between the measure of HPWS and teacher performance $(\gamma=.80, \mathrm{p}<.001)$ as well as a strong positive relationship between the measure of HPWS and helping behaviour $(\gamma=.57, \mathrm{p}<.001)$ was statistically significant thus supporting Hypotheses 1 and $1 \mathrm{~b}$. Besides, it was found that the coefficients of the path from Teacher helping behaviour to teacher performance was also significant $(\gamma=.54, \mathrm{p}=<.001)$, therefore supporting Hypotheses 2.

The correlations estimate for structural equations was .888 for both HPWS and Teacher Performance, .803 for HPWS and Teacher Helping Behaviour as well as .797 for teacher performance and helping behavior, suggesting that the variance of all the variables were moderate as specified in the model as shown in Table 1.

Table 1: Correlations Estimate

\begin{tabular}{|lll|c|}
\hline & & & $\begin{array}{l}\text { Esti } \\
\text { mate }\end{array}$ \\
\hline HPWS & $>-$ & TEACHER_PERFORM & .888 \\
& $>-$ & ANCE & TEACHER_HELPING_- \\
HPWS & $>$ & BEHAVIOUR & .803 \\
TEACHER_PERFO & $<--$ & TEACHER_HELPING_- & .797 \\
RMANCE & $>$ & BEHAVIOUR & .79 \\
\hline
\end{tabular}

This publication is licensed under Creative Commons Attribution CC BY.

\section{Discussion OF THE STUDY}

To assess indirect relationships between HPWS and teacher performance, teacher helping behavior was introduced a mediator variables to test its effect on teacher performance. The results of the Structural Equation Model suggested that the relationship between HPWS and teacher performance cannot be only directional, but there are also indirect relationships that exist between them and helping behavior. Base on structural equation model result, it was observed that the direct effect on teachers performance and HPWS manifest it is, but effects through helping behavior.

According to the findings, the HPWS strongly facilitate helping behavior and enhances teachers' performance. The findings also suggest that teachers helping behavior attitude subsequently promotes students' knowledge, student performance and promote positive school climate. After that, it is quite obvious that the teacher helping behavior as a mediator variable stands a significant role in teacher performance.

Zhang \& Morris (2013) test the mediator role of an employment outcome and found in their research a relationship that exists between high-performance work systems (HPWS) and organizational performance through the mediating effect of employee outcomes. Their paper is based on a sample of $168 \mathrm{firms}$ of six ownership types and in various business sectors operating in China. The results of the research supported that Organizational performance is positively predicted by HPWS and employee outcomes, while employee outcomes positively mediate the 
relationship between HPWS and organizational performance. This finding highlighted the significance of strategic human resource management practices because adoption of work performance system features individually, might not be effective for achieving the institutional goals.

\section{REFERENCES}

[1] Andrew, O. C. \& S. Sofian. 2012. "Individual factors and work outcomes of employee engagement". Procedia-Social and Behavioral Sciences, Volume 40, pp. 498-508.

[2] Appelbaum, S.H. 2000. "A cross method analysis of the impact of culture and communications upon a health care merger." The Journal of Management Development. 22(5), 370-409.

[3] Arthur, J.B. 1994. "Effects of human resource systems on manufacturing performance and turnover." Academy of Management Journal, Vol 37, 670 687.

[4] Bo Zhang \& J. Llewelyn Morris. 2013. "High-performance work systems and organizational performance: testing the mediation role of employee outcomes using evidence from PR China", The International Journal of Human Resource Management, DOI:10.1080/09585192.2013.781524

[5] Boon C, Den Hartog D. N, \& P. Boselie. 2011. "The relationship between perceptions of HR practices and employee outcomes: examining the role of person-organization and person-job fit". The International Journal of Human Resource Management 22: 138-162.

[6] Borucki. C.C. \& M.J. Burke. 1999. "An examination of service-related antecedents to retail service environment: A multiple-stakeholder perspective." Journal of Applied Psychology, 77, 717-729.

[7] Boxall, P. \& K. Macky. 2009. "Research and theory on high-performance work systems: progressing the high-involvement stream". Human Resource Management Journal, 19(1),3-23.

[8] Boxall, P. \& K. Macky. 2016. "High-performance work systems: Involvement versus intensification.” In N. Ashkanasy, R. J. Bennett, M. J. Martinko (Eds.) "Understanding the high-performance workplace: The line between motivation and abuse" (pp. 85-102). New York, USA: Routledge.

[9] Collins, C. J., \& , K. G. Smith. 2006. "Knowledge exchange and combination: The role of human resource practices in the performance of high-technology firms". Academy of Management Journal, 49(3), 544-560

[10] Combs, J., Liu, Y., Hall, A. T., \& D. Ketchen. 2006. "How much do highperformance work practices matter? A meta-analysis of their effects on organizational performance". Personnel Psychology, 59(3), 501-528

[11] Enz, C. A., \& J. A. Siguaw. 2000. "Best practices in human resources." Cornell Hotel and Restaurant Administration Quarterly, 41(1), 48-61

[12] Griffin, M.A., A. Neal, \& S.K. Parker. 2007. "A New Model Of Work Role Performance: Positive Behavior In Uncertain And Interdependent Contexts". Academy of Management Journal, 50(2), 327-347.

[13] Guthrie, J. P. 2001. "High-involvement work practices, turnover, and productivity: Evidence from New Zealand. The Academy of Management Journal, 44(1), 180-190.

[14] Guzzo, R. A., \& K. A. Noonan. 1994. "Human resource practices as communications and the psychological contract." Human Resource Management, 33, 447-462.

[15] Hassan.S. 2016. "Impact of HRM Practices on Employee's Performance". International Journal of Academic Research in Accounting, Finance and Management Sciences, 6(1), 15-22

[16] Heskett, J.L, W.E. Sasser, T.O. Jones, G.W. Loveman, \& L. A. Schlesinger. 1994. "Putting the service profit chain to work." Harvard Business Review, $72,164-175$

[17] Huselid, M.A. \& B.E. Becker. 2011. "Bridging Micro and Macro Domains: Workforce Differentiation and Strategic Human Resource Management". Journal of Management 37(2), 421-428. DOI: 10.1177/0149206310373400

[18] Huselid, M.A. 1995. "The impact of human resource management practices on turnover, productivity, and corporate financial performance." Academy of Management Journal, 38, 635-672.

[19] Huselid, M.A. 1995. "The impact of human resource management practices on turnover, productivity, and corporate financial performance." Academy of Management Journal, 38, 635-672.
[20] Ilgen, D. R., \& E. D. Pulakos. (Eds.) 1999. The changing nature of performance: Implications for staffing, motivation, and development. San Francisco: Jossey-Bass.

[21] Ilgen, D. R., \& Pulakos, E. D. 1999. “Employee performance in today's organizations". In D. R. Ilgen \& E. D. Pulakos (Eds.), The changing nature of performance: Implications for staffing, motivation, an development: 2155. San Francisco: Jossey-Bass

[22] James, L. R., Mulaik, S. A., \& J.M. Brett. 2006. "A tale of two methods". Organizational Research Methods” 9(2), 233-244. DOI: $10.1177 / 1094428105285144$.

[23] Johnson, J.W. 2000. "Linking employee perceptions of service climate to customer satisfaction." Personnel Psychology, 49, 831-851.

[24] Karatepe, O. M. (2013), High-performance work practices and hotel employee performance: The mediation of work engagement. International Journal of Hospitality Management, Volume 32, pp. 132-140 http://dx.doi.org/10.1016/j.ijhm.2012.05.003

[25] Lepak, D. P., Liao, H., Chung, Y., \& E. E. Harden. 2006. “A conceptual review of human resource management systems in strategic human resource management research". Research in personnel and human resources management, 25(1), 217-271.

[26] MacKinnon, D. P., Lockwood, C. M., Hoffman, J. M., West, S. G., \& V. Sheets. 2002. "A comparison of methods to test mediation and other intervening variable effects". Psychological Methods, 7, 83-104.

[27] Munjuri, M.G. 2011. The effect of human resource management practices in enhancing employee performance in Catholic institutions of Higher Learning in Kenya. International Journal of Business Administration, 2(4), p189.

[28] Nadler, D.A. 1992. "Introduction: Organizational architecture: A metaphor for change". In D. Nadler, M. Gerstein, \& R. Shaw (Eds.), Organizational architecture (pp. 1-8). San Francisco: Jossey-Bass

[29] OECD. 2005. Teachers Matter: Attracting, Developing and Retaining Effective Teachers. Paris: OECD

[30] Payne, S.C. \& S.S. Webber. 2006. "Effects of service provider attitudes and employment status on citizenship behaviors and customers' attitudes and loyalty behavior." Journal Of. Applied. Psychology., 91(2), 365-378.

[31] Pfeffer, J. 1994. Competitive advantage through people. Harvard Business School Press: Boston, MA

[32] Piercy, Nigel F. David W. Cravens, Nikala Lane, Douglas \& W. Vorhies 2006. "Driving Organizational Citizenship Behaviors and Salesperson InRole Behavior Performance: The Role of Management Control and Perceived Organizational Support". Journal of The Academy of Marketing Science, Volume 34, No. 2, pages 244-262.

[33] Podsakoff, N. P., Whiting, S. W., Podsakoff, P. M., \& B.D. Blume. 2009 "Individual- and organizational-level consequences of organizational citizenship behaviors: A metaanalysis". Journal of Applied Psychology, 94(1), 122-141. doi: 10.1037/a0013079

[34] Podsakoff, P. M., MacKenzie, S. B., Paine, J. B., \& D.G. Bachrach. 2000 "Organizational citizenship behaviors: A critical review of the theoretical and empirical literature and suggestions for future research". Journal of Management, 26(3), 513-563. doi: 10.1177/014920630002600307

[35] Rhoades, L., \& R. Eisenberger. 2002. "Perceived organizational support: A review of the literature". Journal of Applied Psychology, 87: 698-714

[36] Sattar, T., Ahmad, K ., \& S.M. Hassan. 2015. "Role Of Human Resource Practices In Employee Performance And Job Satisfaction With Mediating Effect Of Employee Engagement”. Pakistan Economic and Social Review, 53(1), 81-96

[37] Schmit, M. J., \& S.P. Allscheid. 1995. "Employee attitudes and customer satisfaction: Making a theoretical and empirical connection". Personnel Psychology, 48, 521-537.

[38] Sun, L.Y., Aryee, S., \& K.S. Law. 2007. "High-performance human resource practices, citizenship behavior, and organizational performance: A relational perspective". Academy of Management Journal, 50(3), 558-577

[39] Vandenberghe, C., K. Bentein, R. Michon, J. C. Chebat, M. Tremblay, \& J. Fils. 2007. "An examination of the role of perceived support and employee commitment in employee-customer encounters." Journal of Applied Psychology, 92, 1177-1187.

[40] Zheng, C. \& D. Lamond. 2010. "Organizational determinants of employee turnover for multinational companies in Asia". Asia Pacific Journal of Management, 27(3), pp. 423-443. 


\section{AUTHORS}

First Author: Shareef Akanbi Ashade, Ph.D Candidate, University Science Islam Malaysia. Bandar Baru Nilai, 71800 Nilai, Negeri Sembilan., shareefashade@gmail.com Second Author: Mikail Ibrahim, Ph.D. Senior Lecturer Faculty of Major Languages, University Science Islam Malaysia
Third Author: Harison Mohd Sidek, PhD. Senior Lecturer. Faculty of Major Language, University Science Islam Malaysia. Bandar Baru Nilai, 71800 Nilai, Negeri Sembilan.

Correspondence Author: Shareef Akanbi Ashade, Ph.D Candidate, University Science Islam Malaysia. Bandar Baru Nilai, 71800 Nilai, Negeri Sembilan., shareefashade@gmail.com 